\title{
SWIFT AND THE PHYSICIANS:
}

\author{
ASPECTS OF SATIRE AND STATUS
}

by

\section{CLIVE T. PROBYN*}

GEORGE ElIOT wrote that "about the year 1829 the dark territories of pathology were a fine America for a spirited young adventurer." The adventurer was Lydgate, who had preferred Rasselas or Gulliver to the Bible or Bayle's dictionary until he discovered the medical profession, "the finest in the world, presenting the most perfect interchange between science and art, offering the most direct alliance between intellectual conquest and the social good". ${ }^{1}$ In 1726, when Swift's Gulliver's travels appeared, pathology had yet to emerge even into twilight: this spirited young surgeon was to end his adventure in the dark territories of misanthropy, condemning his professional colleagues as deceivers all: "a Sort of People bred up among us, in the Profession or Pretense of curing the Sick". ${ }^{2}$ Whereas Lydgate cared "not only for 'cases' but for John and Elizabeth", Gulliver comes to loathe every human individual in a generic hatred. It seems fair to say that the medical profession had a bad press throughout the eighteenth century: it is worth asking why the worst notices were served up by Swift.

Admittedly, in Swift's time, surgery "was still a crude art . . . little in advance of Hippocratic teaching". ${ }^{3}$ The physician's doppelgänger was the quack, the medically unqualified and self-advertising empiric, frantically competing with an emerging (and eventually exclusive) professional body. Often without formal training, the surgeons were lower than the apothecaries and physicians, and it was not until 1745 that the surgeons broke their umbilical liaison with the barbers, whose tasks included delousing, polling and some minor surgery. But even if one grants the dubious professional boundary to the surgeon's art, Swift's cynical comments on the medical profession are obsessive in their frequency. In 1711 he believed that the queen's life was in danger from mutual disagreement among her physicians (a perhaps not unlikely eventuality); ${ }^{4}$ in private, he equated surgeons with butchers, ${ }^{5}$ and in Gulliver's travels he set the physician in the company of "a Lawyer, a Pickpocket, a Colonel, a Fool, a Lord, a Gamester, a Politician, a Whoremunger . . . an Evidence, a Suborner, a Traytor" (p. 280). When not attacking the physician per se, Swift's satire is memorably at its most savage when using anatomical or surgical metaphors. No opportunity is missed to savage their credibility, at a time when the medical profession was lurching unsteadily into being, burdened with charlatanism. Wide permutations on high social status and low professional competence made its members very vulnerable to satiric attack.

* Department of English, University of Lancaster, Bowland College, Bailrigg, Lancaster LA1 4YT.

Medical History, 1974, vol. 18. 


\section{T. Probyn}

Historically, Gulliver is firmly placed as a transitional representative of the profession, having taken each of the two paths open to surgical qualification. He undergoes a four-year apprenticeship with an eminent town surgeon, Mr. Bates, followed by a period of two years and seven months spent at Leiden. In Swift's day, though not yet at the time of Gulliver's putative studentship, Leiden was the leading European seminary for clinical teaching, dominated by the great Herman Boerhaave, tutor of Linnaeus. Boerhaave taught at Leiden until his death in 1738 and it seems reasonable to suppose that Leiden was chosen precisely because of its celebrity. ${ }^{6}$ Swift certainly knew about Leiden and Boerhaave in 1734/5, for he recommended William Fitzherbert to send his son there. The letter is oddly reminiscent of Gulliver's earlier sojourn, for Swift suggests that it might have been better if the son had first been sent to sea or got a commission in the army. ${ }^{7}$ William Pulteney, though "cured" by Boerhaave, according to a letter from Swift to Pope on 2 December 1736, wrote to Swift three weeks later to say that his constitution was "a pretty good one, for it has resisted the attacks of five eminent physicians for five months together". The satirical paradox of equating doctors with worsening illness was no doubt adopted for the occasion, but the interesting point lies in Pulteney's promise to adopt Swift's own characteristically non-clinical regimen, "rising early, eating little, drinking less and riding daily". 8

This combination of the professionals' ineffectiveness and the adoption of his own natural remedy would have afforded Swift a grim satisfaction and reinforced his already low estimate of medical skills. Gulliver, as a modern surgeon, believes and relates as credible truth the most incredible phenomena, and Swift refrains from saying whether this is in response to or in reaction against his medical training. But Gulliver's final word (in the prefatory letter to his cousin Sympson) is unequivocal: until physicians are banished from society he will remain convinced of the indocibility of the Yahoo species.

Leiden provided Gulliver with little protection against credulity. Though the medical school was increasingly to become the new way ahead, it was not yet the passport to enlightenment: additional literary evidence of a profession immobilized by its ignorance is not lacking. Tobias Smollett practised as a doctor over a period of thirteen years after his Glasgow apprenticeship: though he believed that tuberculosis was caused by the drinking of brackish water and that wens could be cured by the application of a dead man's hand, ${ }^{9}$ his attention to the detailed life of his day was scrupulously precise. In Roderick Random (1748) he captured the precise mid-century tensions between the jealous surgeon-apothecaries of the old school (i.e. whose education was by apprenticeship only) and the new men who had at least read, if not been taught, the medical texts. Thus the titular hero recommends himself to the town surgeon $\mathrm{Mr}$. Launcelot $\mathrm{Crab}$ as a shop assistant:

"I may save you the expense of a journeyman, or porter at least, for I understand a little pharmacy, having employed some of my leisure hours in the practice of that art, while I lived with Mr. Potion; neither am I altogether ignorant of surgery, which I have studied with great pleasure and application." "Oh, ho! you did?" says Crab. "Gentlemen, here is a complete artist. Studied surgery! What? In books I suppose? I shall have you disputing with me one of these days, on points of my profession. You can already account for muscular motion, I warrant, and explain the mystery of the brain and nerves-ha! You are too learned for me, $d--n$ me. But let's hear no more of this stuff. Can you bleed and give a clyster, spread a plaister, and prepare a potion?"10 


\section{Swift and the physicians}

Such were the bulwarks within the profession against the recent researches of the anatomist and cerebral pathologist: the gap between the eminent analyst and the lamely educated practical empiric afforded elbow room for instant miracle cures and every outré panacea imaginable.

The scale of medical satire in the seventeenth century was sufficient to provide later times with conventional patterns for their continuing criticism. For example, the bizarre ingredients of the apothecary's art. In the most famous medical satire up to 1726, Sir Samuel Garth's The dispensary (1699), the old-fashioned and retrenched attitudes of the apothecaries are reflected by their stock-in-trade:

Here, Mummies lay most reverently stale,

And there, the Tortois hung her Coat o' Mail;

Not far from some huge Shark's devouring Head

The flying Fish their finny Pinions spread.

Aloft in Rows large Poppy Heads were strung,

And here, a scaly Alligator hung.

In this place, Drugs in musty Heaps decay'd,

In that, dry'd Bladders, and drawn Teeth were laid. ${ }^{11}$

A similar device and intention occurs in Gulliver's description of the doctor's emetic, a cure worse than the ailment itself: "Herbs, Minerals, Gums, Oyls, Shells, Salts, Juices, Sea-Weed, Excrements, Barks of Trees, Serpents, Toads, Frogs, Spiders, dead Mens Flesh and Bones, Beasts and Fishes ... a Composition for Smell and Taste the most abominable, nauseous and detestable, that they can possibly contrive" (pp. 237-8). Attacks on the virtuoso provide the larger context for such details, in Butler's Hudibras (1663-78), Shadwell's The virtuoso (1676), in the portrait of Sir Nicholas Gimcrack in Tatler No. 216, and Fossile in Pope, Gay and Arbuthnot's Three hours after marriage (1717). Burns' Death and Dr. Hornbook (1785) also satirizes the grocer-turned-apothecary (reversing their actual separation in 1617) in the manner of Garth (see stanzas 20-22). Indeed the literature of the quack and antiquarian, obscure experimentalist and pedant is a considerable feature of eighteenthcentury culture. For every skilled physician, a Cheselden or a Mead, there was a gaggle of unskilled quacks-St. André, John Taylor, Joanna Stephens, Joshua Ward, Sir William Read, and James Graham-to mention only the most celebrated, and in some cases the most wealthy, of the quacks. ${ }^{12}$

Swift's artistic reaction to the medical profession was unequivocally to throw in with Shadwell and Garth, Rabelais, Molière and Le Sage: the tradition of the homicidal doctor, for example, may be traced back as far as Juvenal. ${ }^{18}$ But Swift is distinct from such a tradition in the scope, intensity and degree of exploitation he makes of his materials. The moral effect of his satire often depends upon, but actually transcends parody of, anatomical and surgical operations. ${ }^{14}$ In his institutional satire on the College of Physicians he links specific medical satire with a universal malady: the College is alongside Bedlam, Gresham College, Westminster and Guildhall; professors of physick are thus only one manifestation of a disease which also afflicted exponents of natural philosophy, divinity and the law. Thus in $A$ tale of a tub, described by one commentator "the locus classicus for the satire on [medical] systematists . . . written precisely at the time (1696-1704) when iatromechanists were 


\section{T. Probyn}

at their zenith", 15 the "Whispering Office" is erected as a prophylactic for all those who are "Hypochondriacal, or troubled with the Cholick . . . Eavesdroppers, Physicians, Midwives, small Politicians, Friends fallen out, Repeating Poets, Lovers happy or in Despair, Bawds, Privy-Counsellors, Pages, Parasites and Buffoons; in short, of all such as are in Danger of bursting with too much Wind". ${ }^{16}$ The arbitrary syntax of the list denotes a levelling contempt for all, and the unflattering theory of flatulence provides a literal and symbolic deflation-system by relating all intellectual pretension to an involuntary motor function of the "lower" organs. Similarly, in $A$ digression on madness, a course of physick is a cause of scribbling: flatulence and inspiration bear the same relationship to each other as creative writing and the need for physical evacuation. The cure in both cases is the caustic of satire, the equivalent of the physician's potions. In this brief example it may be seen how Swift deploys anatomical language for large-scale satiric effects: specific anti-medical satire is merely one detail among many, but nevertheless provides the overall metaphoric vehicle. This technique was well established in Swift's satiric arsenal when Gulliver's profession as surgeon was selected.

Gulliver is, $a b$ initio, a member of a profession whose training was known to be of a variable and sometimes non-existent competence, a detail which tends to qualify Gulliver's self-appointed role as moral diagnostician. Swift's own immediate experience provided undeniable reaffirmations of the traditional medical criticisms, and some of these were notorious enough to give specificity to this aspect of Gulliver's characterization. Swift's friend, the "too speculative" George Berkeley, Bishop of Cloyne, was one of the last notable clerical amateurs to fade from the medical scene: his book recommended the almost universal curative powers of a weak infusion of tar. ${ }^{17} \mathrm{Up}$ to the date of publication of the Travels one could note the following: Sir William Read (d. 1715), who began life as a tailor and became a quack and mountebank (knighted in 1705 for his services to seamen and soldiers, he became the queen's oculist: Swift declined Henley's invitation to visit Read in 1711 ${ }^{18}$ ); Joshua Ward, twice satirized by Pope in the Imitations of Horace as the inventor of the "drop and pill", whose services were variously employed by Fielding and Gibbon and who re-located George II's thumb; and, above all, Nathanael St. André, whose astonishing career makes the Scriblerian satires on him look like documentaries. His biography was the perfect model for the quack syndrome. Erstwhile fencing- and dancing-master, and medically quite unqualified, he was appointed surgeon and anatomist to the royal household by George I in 1723, apparently on the strength of his linguistic ability. ${ }^{19}$ Events suggested that the criterion of royal preference was not medical perspicacity alone, if at all, for St. André was utterly duped by Mary Tofts' claim to have been delivered of seventeen rabbits. Though the fraud was discovered, St. André nevertheless kept his post as royal anatomist. During his lifetime he had ministered to Lord Peterborough and on one occasion treated Pope. There were many such shadowy practitioners and one might conclude from this short list that society's judgement of its medical men was somewhat uncertain. Tolerance of quacks seems remarkably high among those who might, one supposes, have been better informed. Proven medical expertise seems not to have been the sole criterion for social advancement, and contemporary satire often links polite society with medical credulity. 


\section{Swift and the physicians}

Pope captured the prevailing Scriblerian response, both to the training and modus vivendi of such men, in his couplets on Ward. As in Swift, the portrait is bolstered with implications of inappropriate modishness and by charges that elementary humanist inhibitions are being flaunted by the profession:

He serv'd a 'Prenticeship, who sets up shop:

Ward try'd on Puppies, and the Poor, his Drop;

Ev'n Radcliff's Doctors travel first to France,

Nor dare to Practise till they've learn'd to dance. ${ }^{20}$

Pope's caricature makes the quack a socialite: mercantile unscrupulousness combining with facile social graces make the successful physician. Society appears to demand no more. With an obvious ambiguity Gulliver glosses the Profession of medical men as their Pretense. John Gay's poem Newgate's garland (1724: but possibly written by Swift) slightly enlarges the field: "Physicians and Lawyers, who take their Degrees/ To be learned Rogues, call their Pilfering, Fees."21 Although Swift does share in this anti-professional satire, his most effective attacks on the doctor are by contrast extremely specific. In the most famous, the figure of the doctor in the Academy of Lagado, Swift goes straight for the Cartesian jugular: mechanistic language is designed to expose the iatromechanists from within their own specialism. Gulliver is troubled with a "small Fit of the Colick", and he witnesses the extraordinary remedy perpetrated on a dog "by contrary Operations". The Operator

had a large Pair of Bellows, with a long slender Muzzle of Ivory. This he conveyed eight Inches up the Anus, and drawing in the Wind, he affirmed he could make the Guts as lank as a dried Bladder. But when the Disease was more stubborn and violent, he let in the Muzzle while the Bellows was full of wind, which he discharged into the Body of the Patient, then withdrew the Instrument to replenish it, clapping his Thumb strongly against the Orifice of the Fundament; and this being repeated three or four Times, the adventitious Wind would rush out, bringing the noxious along with it (like Water put into a Pump) and the Patient recovers. ${ }^{22}$

Gulliver, the surgeon, understandably declines the opportunity of becoming the next patient of the mechanical doctor and leaves the operator trying to resuscitate the dog. The detail of using a pair of bellows for this incident Swift could have found in various sources, in Rabelais, in Sprat's account of Hooke's experiments in the History of the Royal Society, in Shadwell's The virtuoso. ${ }^{23}$ The effect of adding it is to make monstrous physical mock of the experts who conceived of the body as a simple machine subject to the laws of mechanics and hydrodynamics. An epitome of such current theories was Hoffmann's Fundamenta medicinae (1695): "Our body is like a machine or automaton whose organs, varying in shape and size, are disposed and constructed in a particular order and position. These organs must be moved and animated by the fluid parts of the body." 24

The narrowly mechanical thrust of Swift's satire stands in stark contrast to the usual cure for such a commonplace ailment and shows Swift deliberately reaching out for a specific target. To us Swift's operator is no less credible than his contemporary rivals. The sometimes credulous author of The skeptical chymist, Robert Boyle, a target for Swift's scientific satires, offered eighteen remedies for the colick, including 


\section{T. Probyn}

a solution of fresh stone-horse dung in white wine, mastic and the yolk of a new-laid egg, and the "volatile salt of pigeon dung". ${ }^{25}$ The less chemically-advanced and more proletarian directive, Moncrieff's The poor man's physician (1712) recommended the "Heart of a Lark bound to the Thighs", "dry Ox-dung drunk in Broth", or "Wolfs Dung, Guts, or Skin eaten". ${ }^{26}$ Swift's anality is rarely gratuitous: here, anality and Cartesian mechanism are synthesized in order to expose the preposterous gap between a physical ailment of the body and intellectually engendered cures. In such a detail the apparently preposterous satire merely reflects an equally improbable (and repulsive) actuality. In the absence of real medical knowledge, Swift implies, the choice lies merely between fashionable ingenuities. The famous anatomy of the brain passage in $A$ tale of $a t u b$ is a satiric arabesque of contemporary mechanistic cerebral anatomy. The following extract draws on Cartesian mechanism, Galenical humours and Hippocratic spirits (the combination is mocked by its own complexity):

For, it is the Opinion of Choice Virtuosi, that the Brain is only a Crowd of little Animals, but with Teeth and Claws extremely sharp, and therefore cling together in the Contexture we behold, like the Picture of Hobbes's Leviathan, or like Bees in perpendicular Swarm upon a Tree, or like a Carrion corrupted into Vermin, still preserving the Shape and Figure of the Mother Animal. That all Invention is formed by the Morsure of two or more of these Animals, upon certain capillary Nerves, which proceed from thence, whereof three Branches spread into the Tongue, and two into the right Hand. They hold also, that these Animals are of a Constitution extremely cold; that their Food is the Air we attract, their Excrements Phlegm; and that what is vulgarly called Rheums, and Colds, and Distillations, is nothing else but an Epidemical Looseness, to which that little Commonwealth is very subject, from the Climate it lyes under. ${ }^{27}$

For Swift it was an easy conversion to turn the indefinable animal spirits of the Hippocratic and Galenic tradition into spirited animals which actually crawled around inside the brain of the modern virtuoso, here exercising his smattering of medical knowledge.

There is no evidence of systematic medical study by Swift in relation to such medical parodies quoted above. But, and this is also true of his economic tracts such as $\boldsymbol{A}$ modest proposal and the Drapier's letters, Swift usually based his parodies on the salient points and features of specific works. In the field of cerebral anatomy it is inconceivable that he was working solely under inspired intuition. Indeed, the success of the anatomy in the Tale depends on the ready recognition of a few anatomical "facts" by the reader. Swift himself had recently been reading one modern and intelligent scientific digest, William Wotton's Reflections upon ancient and modern learning (1694), extensively attacked in the Tale and The battle of the books (1704). At one point, in chapter XVII, "Of ancient and modern anatomy", Wotton popularizes the cerebral anatomy developed by Thomas Willis (Cerebri anatome, 1659) and Marcello Malpighi (Epistolae anatomicae, 1662):

the manner of the forming of the Animal Spirit in the Brain was wholly unknown. In Order to the Discovery whereof, Malpighius by his Microscope found that the Cortical Part of the Brain consists of an innumerable Company of very small Glandules, which are all supplied with Blood by Capillary Arteries; and that the Animal Spirit, which is separated from the Mass of Blood in these Glandules, is carried from them into the Medulla Oblongata through little Pipes, whereof one belongs to every Gland, whose other End is inserted into the Medulla Oblongata, and that these numberless Pipes, which in the Brain of some Fishes look like the Teeth of a small Ivory 


\section{Swift and the physicians}

Comb are properly called the Corpus callosum, or the Medullar Part of the Brain. This Discovery destroys the Ancient Notions of the Uses of the Ventricles of the Brain, and makes it very probable that those Cavities are only Sinks to carry off excrementitious Humours, and not Store-Houses of the Animal Spirit. ${ }^{28}$

Swift's anatomy in the Tale, placed in the mouth of a cocksure pedant, is a direct and scornful version of this passage in Wotton, it seems to me, as much as a parody of Wotton's primary sources. Swift's contemptuous exuberance appropriately returns Wotton's crushing scorn for the ignorance of the Ancients in medicine. The tone of Swift's passage is therefore functional, for Swift's allegiances in medicine were probably with Galen and Hippocrates. In 1715 his library contained four volumes of Galen's works (three in Latin published in 1549 and Epitome Galeni operum, 1643), and his poem The answer (1724) indicates the Galenic reading Swift had done in order to understand for himself the debilitating bouts of labyrinthine vertigo (Ménière's syndrome) which afflicted him. The passage in question alludes to Galen's description of the hearing mechanism in De usu partium corporis:

Galen most acutely shows you

(Consult his Book de Partium usu)

That from each Ear, as he observes,

There creeps two auditory Nerves,

(Not to be seen without a Glass)

Which near the Os petrosum pass;

Thence to the Neck; and thorow there;

One goes to this, and one to t'other Ear. ${ }^{29}$

Desperate bouts of depression and terrifying dizziness are thus turned into jaunty octosyllabics.

Following Temple's contribution to the Ancients and Moderns controversy, and reflecting the seventeenth-century stage of medical contentions, Swift matches Galen against Paracelsus in The battle of the books. Their contest has an unknown outcome, for a convenient gap in the manuscript absolves Swift from adjudicating between their respective merits. But Swift was well prepared for the Ancients' victory. He had read Celsus' De medicina (1592 edition), one of the first medical texts to be reprinted in the Renaissance, and which described treatment of diseases by diet and regimen, as well as by drugs and surgery. The entry Medicina Salernitana (1605) in Swift's library catalogue may have been the Regimen Sanitas Salernitatum, a product of the first organized (tenth- to eleventh-century) medical school in Europe, particularly remembered for its oft-quoted couplet: "Use three Physicians still, first Doctor Quiet,/Next Doctor Merryman, and Doctor Diet". If the first and third precepts remind us of Swift's advice to Pulteney, the second might suggest that Swift's mordant and comic medical satire was a special sort of autodidactic therapy. The works of Paracelsus (the 1658 edition) and Gibson's Of the anatomy of human bodies (1697) complete the list. The choice of texts suggests careful attention: each one (except perhaps the last) is a landmark in the history of medicine and when taken together provide an epitome of its evolution.

Apart from one Scriblerian spoof, Arbuthnot's [?] The anatomist dissected (1727), a critique written against St. André by "Lemuel Gulliver, Surgeon", ${ }^{30}$ it is remarkable 


\title{
C. T. Probyn
}

that Swift's detailed, informed and savage attack on the medical profession provoked so little response. However, anyone assuming the task of defending the credibility of the profession in the closing months of 1726 would have had a difficult task, and one piece of evidence does suggest how precarious any such apologia would be. Two months after the publication of Gulliver's travels, and shortly after the Tofts case, Thomas Braithwaite, surgeon, wrote this:

\begin{abstract}
It is well known that the Town has lately been amused with idle Relations by the Gullivers, St. Andre's and Howards of the Age; and it is as certain that these Amusements have been carried on in their respective Capacities, of Surgeons, Captains, Dancing-Masters, Anatomists, Men-Midwives, Warreners, Coney-Catchers, \&c. and they don't stick to tell us that there are Men of the Size of one's little Finger, and others Sixty Foot high, and that there are Flying Islands and Rational Horses; that Human Excrements may be reduced to their primitive Ingredients, or at least may be changed into PORRACEOUS Matter, and that Mary Toft of Godliman has been delivered of Seventeen Rabbits .... When I reflect upon this strange Gallimatias, I am chagrin'd to think that the valuable Arts of Surgery and Anatomy must necessarily be brought into Contempt by such monstrous Relations. This consideration has induced me to lay open some of the gross Impositions, as far as they relate to the Profession; and as some of these Accounts are not only false, but even bordering upon Farce, I am inclined to treat them in the Manner I think, they deserve. ${ }^{31}$
\end{abstract}

This was the unavoidable truth: the enormous success of Gulliver's travels exactly coincided with embarrassing confirmation of Swift's charges of quackery in the profession. The contiguity of medical men and modishness, sailors and surgeons, dancers and druggists, had become identity both in fact and in satire, and nothing that the ingenuous Braithwaite could do would deny the fact. In Swift's particular case, moreover, the satire was related to a more fundamental preoccupation: antimedical parody was only one of many effects, but one which lay at the core of Swift's moral criticism.

Swift's relationship with medicine, a love-hate paradox, is concealed behind the Ancients and Moderns controversy. Undoubtedly an Ancient, Swift was in business to revile modern exponents, and in order to do this he used parody. From this 'local' effect grows a larger and more universal satiric mode which superimposes a moral significance on the merely physical. The position of the surgeon between these polarized opponents is central and pivotal. The point is clearly made in Campbell's The London tradesman (1747), in which the physician is second only to the divine in importance. Campbell distinguishes the physician from the surgeon by stating that the latter

is only employed in the Cure of Wounds, Bruises, Contusions, Ulcers, and Eruptions in the outward Parts, in Trepanning, Cutting, or Scarifying, and Amputations of any of the Limbs or Members, that require these Operations. He applies only topical Medicines, that is, to the outward Parts of the Body affected . . . but is rarely concerned in any inward Applications. 28

In Swift the vocation of preacher and the avocation of satirist mutually reinforce the conviction of human corruption. Everybody else works at surface level, including the surgeon. The medical man is professionally unconcerned with moral anatomy, which is the preserve of the divine or the satirist: he is their complement, the agent of physical preservation called into being by the default of nature or the intemperance 


\title{
Swift and the physicians
}

of man. This is certainly the Houyhnhnm view, and Swift reserves surgical language for those who were incurably corrupt: partly political leaders may be cured of their fanaticism by the mutual transplantation of lobotomized brains (in the Academy of Lagado); the whore and the beau in A tale of $a t u b$ are object lessons in the limitations of surgery:

\begin{abstract}
in most Corporeal Beings, which have fallen under my Cognizance, the Outside hath been infinitely preferable to the $I n$ : Whereof $I$ have been farther convinced from some late Experiments. Last week I saw a woman flay'd, and you will hardly believe, how much it alter'd her Person for the worse. Yesterday I ordered the Carcass of a Beau to be stript in my Presence; when we were all amazed to find so many unsuspected Faults under one Suit of Cloaths. Then I laid open his Brain, his Heart, and his Spleen; But, I plainly perceived at every Operation, that the farther we proceeded, we found the Defects encrease upon us in Number and Bulk: From all which I justly formed this Conclusion to my self; that whatever Philosopher or Projector can find an Art to sodder or patch up the Flaws and Imperfections of Nature, will deserve much better of Mankind, and teach us a more useful Science, than that so much in present Esteem, of widening and exposing them (like him who held Anatomy to be the ultimate End of Physick)."0
\end{abstract}

In this bleak epitome of the antagonism between the moral and physical worlds Swift's moral surgery reveals depths of corruption stretching far beyond surgical reparation. If the patient is morally incurable then his or her physical state will be patently preferable. Surgery cannot be performed, however, on the human species nor on human types: hence the disturbing quality in Swift's focus. Even the clinical detachment of the surgeon is overwhelmed by the proliferation of moral disease, and Swift shows here how the human subject, though pinned and wriggling, will always outstrip the ingenuity of the most skilled operator. Hence the vast irony, for Pope as well as Swift, of the medical Neros theorizing while the patient expires unnoticed. Pope reserved the line "Physic of Metaphysic begs defence" for the cataclysmic end of The Dunciad (Book IV, 1. 645) in order to dramatize the failure. In the passage from the Tale quoted above, and as some critics have noted, Swift is suggesting that the moral reality is so appalling that it is better to avert the eyes altogether. Pope was hardly more adventurous: he introduces his Essay on Man (1733-4) with the same caution:

The Science of Human Nature is, like all other Sciences, reduced to a few clear points: There are not many certain Truths in this world. It is therefore in the Anatomy of the Mind as in that of the Body; more good will accrue to mankind by attending to the large, open, and perceptible parts, than by studying too much such finer nerves and vessels, the conformations and uses of which will for ever escape our observation.

The remorseless attention paid to the human anatomy and the keen satirical edge provided by the surgical narrator (both in the Travels and in A tale) return time and time again to this point. By harping on such details Swift realizes the "quintessentially humanistic" theme of the frailty of man: one recent and influential discussion of Gulliver's experiences concludes:

When all is said, the experiences which transform him from a fairly bright young surgeon into a raging megalomaniac have been almost as largely physical as intellectual and psychological ... the fourth voyage seems busy with apparently gratuitous details of injury and pain."4 


\section{T. Probyn}

Yet the details are not gratuitous, though the extent and number of such incidents may strike an obsessional note. By starkly focussing on the legendary quack Swift was dramatizing his moral frustration, living in a world where one sort of degeneration went apparently undoctored whilst measureless but ultimately futile ingenuity was applied to conceal the irreversible fact of physical decline. It is therefore of pointed significance that after his Fourth Voyage Gulliver throws overboard every vestige of loyalty to the medical profession. He has suppressed his animal nature and become a moral anatomist. Among the Houyhnhnms he lived in a society where the natural state of life is health and where disease is unknown. In giving perfect health to the horses, however, Swift has indicated its unattainable nature for man and emphasized that disease is the normal state of his being, only exacerbated by self-indulgence. Thus the biographical form of the Travels gives fictive flesh to the bones of an otherwise absurdly schematised separation of the physical and moral. As a surgeon Gulliver is trained to deal with the former: in the event he lurches away from the physical realities (because they are unbearable) and ends on a solitary pinnacle of utter moral isolation. The terminology of the surgeon, and the contemporary associations of credulity, provide the perfect satirical vehicle for the disparity which tormented Swift, that between the Outside of corporeal beings and the Inside. In his effort to purify himself of human vices Gulliver the erstwhile surgeon is allowed to cut away everything including his humanity: as Swift shows, the operation leaves him a hollow man, a moral freak who can have no place in human society as it actually exists.

\section{REFERENCES}

1. Middlemarch, 1872, Signet Classics edition, pp. 143, 146.

2. Gulliver's travels, prose works of Jonathan Swift, ed. Herbert Davis, 14 vols., Oxford, Blackwell, 1939-68, vol. 9, p. 237. All references to this edition.

3. Zachary Cope, The history of the Royal College of Surgeons of England, London, Anthony Blond, 1959, p. 6.

4. The journal to Stella, ed. Harold Williams, 2 vols., Oxford, Clarendon Press, 1948, vol. 1 , p. 311.

5. Thoughts on various subjects, prose works, vol. 1, p. 244.

6. See G. A. Lindeboom, Herman Boerhaave: the man and his work, London, Methuen, 1968, and Samuel Johnson's Life of Boerhaave (based on the funeral oration of Albert Schultens of 1738) published in The Gentleman's Magazine, 1739, pp. 37-38, 72-73, 114-116, 172-176. W. B. Carnochan too briefly notes Gulliver's medical role in 'Some roles of Lemuel Gulliver', Texas Studies in Literature and Language, 1964, 5: 520-522. For medical references to Swift (1846-1958), see J. B. Gilbert, Disease and destiny, London, Dawsons of Pall Mall, 1962, and in addition to those cited below, T. G. Wilson, 'The mental and physical health of Dean Swift', Med. Hist., 1958, 2: 175-190, which outlines some of the bizarre myths which medical interpreters have foisted on Swift (e.g. those of Sir W. R. Brain). I am not here concerned with Swift's own medical history. For the last two references I am grateful to Edwin Clarke, M.D., F.R.C.P. See also T. G. Wilson, 'Swift and the doctors', Med. Hist., 1964, 8: 199-216, for some related discussion.

7. The correspondence of Jonathan Swift, ed. Harold Williams, 5 vols, Oxford, Clarendon Press, 1963-65, vol. 4, pp. 307-309. Hereafter Correspondence.

8. Correspondence, vol. 4, pp. 546, 552. Swift's belief in the virtues of vigorous exercise was fanatical. 


\section{Swift and the physicians}

9. See Smollett's Essay on the external uses of water, London, 1752, reprinted in Bull. Hist. Med. (Johns Hopk. Univ.), 1935, 3: 31-38; C. E. Jones, 'Tobias Smollett . . . the doctor as man of letters', J. Hist. Med., 1957, 12: 227-348. For Smollett's medical training, see Donald Bruce, Radical Dr. Smollett, London, Gollancz, 1964, chapter 2.

10. The works of Tobias Smollett, ed. J. P. Browne, 8 vols., London, Bickers \& Sotheran, 1872, vol. 2, p. 38. Town surgeons, according to R. Campbell's The London tradesman, London, 1747, p. 52, monopolized the treatment of venereal disease, 'upon which alone the Subsistence of three parts in Four of all the Surgeons in Town depends.' Smollett's Mr. Crab, himself trained only by apprenticeship, has a name which corroborates the claim.

11. The dispensary, ed. W. J. Leicht, Heidelberg, Englische Textbibliothek, 1905, Canto II, 11. 122-129.

12. For a brief account of some of these figures, see Dictionary of National Biography, and Sir George Clark, $A$ history of the Royal College of Physicians of London, 2 vols., Oxford, Clarendon Press, 1966, vol. 2, pp. 513-515. The wealth of some physicians was substantial: see Dorothy Marshall, English people in the eighteenth century, London, Longmans, 1956, pp. 53, 133-135. See also note 20 below.

13. For Juvenal's homicidal doctor, see Satires, vol. 10, p. 221. For Swift's, see Verses on the death of Dr. Swift, Swift's poems, ed. Harold Williams, 2nd ed., Oxford, Clarendon Press, 1958, vol. 2, p. 557: 'He'd rather chuse that I should dye,/Than his Prediction prove a Lye'. For the dramatic tradition, see $\mathrm{H}$. Silvette, The doctor on the stage, Knoxville, University of Tennessee Press, 1967.

14. Two important articles should be consulted: Mary Clare Randolph, 'The medical concept in English renaissance satiric theory: its possible relationships and implications', Studies in Philology, 1941, 38: 125-157; and Kathleen Williams, 'Animal rationis capax: a study of certain aspects of Swift's imagery', J. Eng. lit. Hist., 1954, 21: 193-207.

For commentary on the Tale and anatomical imagery, see M. K. Starkman, Swift's satire on learning in 'A tale of a tub', Princeton, Princeton University Press, 1950; and R. F. Paulson, Theme and structure in Swift's 'Tale of a tub', New Haven, Yale University Press, 1960. Steward LaCasce gives a thoughtful account of the ancient and modern context in 'Swift and medical extremism', J. Hist. Ideas, 1970, 31: 599-606. Anatomical metaphors are not, of course restricted to the satirist. In his preface to the Political anatomy of Ireland, Dublin, 1719, Sir William Petty develops the body politic concept at length (the metaphor lends precision to the analysis): for Swift's savage parody of the economist's jargon, see $A$ modest proposal: 'as students in medicine practise their inquiries upon cheap and common animals, and such whose actions they are best acquainted with, and where there is the least confusion and perplexure of parts, I have chosen Ireland as such a political animal . . . I have had only a common knife and a clout ... however, my rude approaches being enough to find whereabout the liver, and spleen, and lungs lie, tho' not to discern the lymphatick vessels; the Plexus, Choroidus, the Volvali of Vessels within the finer parts.' (Tracts chiefly relating to Ireland, Dublin, 1769, pp. 288-289.)

15. G. S. Rousseau, 'Sowing the wind and reaping the whirlwind: aspects of change in eighteenth-century medicine', Studies in change and revolution, ed. Paul J. Korshin, Menston, Scolar Press, 1972, p. 151.

16. A tale of a tub, ed. A. C. Guthkelch and D. Nichol Smith, 2nd ed., Oxford, Clarendon Press, 1958, pp. 107-108. Hereafter Tale.

17. Siris. A chain of philosophical reflections and inquiries concerning the virtues of tar-water, London, 1744. John Wesley's Primitive physic, London, 1747, though very influential (see Clark, op. cit., p. 541) has been described as 'an absurd, fantastic compilation of uncritical folk-lore' (J. H. Plumb, England in the eighteenth century, London, Penguin Books, 1950, p. 96). Swift believed that maladies affected by Irish ladies could be eradicated by controlling their demand for imported English luxuries and stated 


\section{T. Probyn}

(Prose, vol. 12, p. 68): 'if they could be contented with their native wholesome slops for breakfast, we should hear no more of their Spleen, Hystericks, Cholicks, Palpitations and Asthmaes.' (For these, Wesley recommended prolonged electric shock treatment.) For Swift's belief that women in particular promoted the treatment of imaginary diseases, see Prose, vol. 11, p. 254.

18. Journal to Stella, vol. 1, p. 240.

19. For St. Andrés biography, see B. Hutchinson, Biographica medica, 2 vols, London, J. Johnson, 1798, vol. 2, p. 355-365. For the Tofts case, see S. A. Seligman, 'Mary Tofts-the rabbit breeder', Med. Hist., 1961, 5: 349-360.

20. Epistle to Augustus, 1737, vol. 11, pp. 181-184. The whole question of the doctor's social status (actual and imagined) needs detailed investigation. The associations of modishness suggest that his mobility upwards was not acceptable to some. For some comments, see P. Laslett, The world we have lost, 2nd ed., London, Methuen, 1967, p. 38; Silvette, op. cit., pp. 260-261 ; C. D. O'Malley, 'The English physician in the earlier eighteenth century', England in the Restoration and early eighteenth century, ed. by H. T. Swederberg, jr., Berkeley, Los Angeles, London, University of California Press, 1972, pp. 145-161. Campbell's The London tradesman, op. cit., 1747, discusses the uncertainty of the surgeon's professional status and the deficiences in all branches of the physicians' art. See pp. 49-52 for the necessary qualifications of the naval surgeon. Interestingly enough, Campbell, like Swift's Houyhnhnms, believes that 'in the first Ages of the World' there was no need for doctors, for there was no vice.

21. Swift's poems, ed. Harold Williams, 3 vols., 2nd ed., Oxford, Clarendon Press, 1958, vol. 3, pp. 1111-1115.

22. Prose, vol. 11, p. 165. LaCasce, op. cit., pp. 603-605, discusses the Hippocratic background of this passage, and Dr. John Woodward as its contemporary target.

23. See further Marjorie Nicolson and Nora M. Mohler, 'The scientific background of Swift's "Voyage to Laputa", Ann. Sci., 1937, 2: 299-334. I have discussed further links between Boyle and Swift in a forthcoming article 'Gulliver and the relativity of things: a commentary on method and mode, with a note on Smollett', in Renaissance and Modern Studies.

24. Quoted in Lester S. King, A history of medicine: selected readings, London, Penguin Books, 1971, p. 128.

25. The philosophical works of . . Boyle, ed. Peter Shaw, 3 vols., 2nd ed., London, printed for J. Innys and others, 1738, vol. 3, pp. 615-618.

26. Quoted in J. D. Comrie, A history of Scottish medicine, 2 vols., London, Wellcome Historical Medical Museum, 1932, vol. 2, p. 423.

27. Tale, p. 277. For a commentary on the background of this passage see Starkman, op. cit., pp. 26-31.

28. Reflections upon ancient and modern learning, London, 1694. pp. 197-198. The case for Swift's indebtedness to this passage is argued in my forthcoming note 'Swift's anatomy of the brain: the hexagonal bite of poetry', in Notes and Queries.

29. Swift's poems, vol. 2, p. 367 and note. For Swift's library, see Swift's library, ed. Harold Williams, Cambridge, Cambridge University Press, 1932.

30. Attributed to Arbuthnot in Marjorie Nicolson and G. S. Rousseau, This long disease my life: Alexander Pope and the sciences, Princeton, Princeton University Press, 1968, pp. 114-115.

31. Remarks in a short narrative of an extraordinary delivery of rabbits performed by $\mathrm{Mr}$. John Howard, surgeon at Guildford (28 October 1726). The pamphlet is bound up with others in the British Museum as Tracts relating to Mary Tofts, which includes Hogarth's engraving 'Cunicularii, or the wise men of Godliman in consultation'. R. F. Paulson is sceptical of the tradition which claims that some London doctors sponsored this piece (see Hogarth, his life, art and times, 2 vols., London and New Haven, Yale University Press, 1971, vol. 1, p. 168), but quotes Lord Hervey's letter to 


\section{Swift and the physicians}

Henry Fox indicating that at least one famous doctor (i.e. Arbuthnot) was "convinced of the truth of what St. André says.'

32. Campbell, op. cit., p. 47.

33. This passage has provoked much critical response. For some recent views, see Essays in criticism, 1970, 20: 496-497; 1971, 21: 115-116; 417-418; all in answer to Claude Rawson's 'Order and cruelty: a reading of Swift (with some comments on Pope and Johnson)', Essays in Criticism, 1970, 20: 24-25.

34. Paul Fussell, The rhetorical world of Augustan humanism, Oxford, Clarendon Press, 1965, pp. 128-129. 